DOI: 10.15642/JIIS.2018.12.1.1-16

\title{
CONTINUITY AND CHANGE IN SUNDANESE PANANYAAN Contesting an Islamicate Tradition in West Java
}

\author{
Asep N. Musadad \\ Islamic College of Sunan Pandanaran, Yogyakarta - Indonesia | asepnahrul92@gmail.com
}

\begin{abstract}
This paper aims to discuss the development of pananyaan, a name for Sundanese-Priangan local shaman in terms of continuity and change. Using ethnographical method, it will provide an anthropological account of these elderly people through the investigation of the major shifts of them and their meanings, to the grand narration of Islamization process. The exploration based on the research questions leads to several conclusions. The existence of pananyaan has become primordial nature of the belief toward supernatural being. There are, at least, several major shifts in the origins pananyaan to the present. First, the shift of domestic spiritualism from local spirit to Islamic saints that reflected an elementary form of the intersection of Islam and local customs. Second, the emergence of abli bikmah, that reflected such an outward appearance in the intersection as represented by several hybrid incantations and supernatural powers. Third, the contemporary shaman, whose Islam and local customs are united in one fashion with the influence of modern determinations. In addition, the still-taking place Islamization has become a challenge for the next development of pananyaan.
\end{abstract}

Keywords: Pananyaan, Continuity and Change, west Java, Islamization.

\section{Introduction}

The existence of pananyaan (in polite word: patarosan), a name for local shaman in Sundanese local genius, remains neglected in many ways $^{1}$ and at the same time has shown a living experience of Sundanese

${ }^{1}$ For the best of my knowledge, the particular scholarly articles concerning pananyaan are not to be found before I wrote the article entitled A Preliminary Sketch of Pananyaan and Their Magical Spells in Sundanese Culture, a paper presented in ICSAI (International Seminar 
Muslim, up to present day. There are reasons to belief regarding pananyaan as the "living evidence" to present the nature of Sundanese Muslim, in one hand, and the legacy of Islamization in the other hand. The ultimate meaning of pananyaan today encompasses the nucleus of shaman, traditional healer, spiritual practitioner, astrologer, and-in turn-Islamic priest which equivalent to abli bikmah.

It is commonly said that Sundanese Islam, in general, was a representation of the "Islam-santr" variant-in Clifford Geertz's typology of Javanese ${ }^{2}$ - to be spread mainly in Sundanese-speaking area. Unlike the fate of Javanese Muslim, which reflected such heterogeneous character with the strong legacy of previous religious life and practices, the course of Sundanese Muslim led to a uniform variant. In Sundanese-speaking area, Islam has a major role in constructing the nature of Sundanese identity. In this case, Sunda has been identical with Islam, with the result that the "Sundanese non-Muslim" remains strange in the mind of Sundanese people until recent times.

This leads one to argue that the legacy of Hindu-Buddhist values has no significant considerable impact in Sundanese Muslim in the same manner as Javanese. ${ }^{3}$ The incorporation of Islamic spectrum and these values has resulted the particular kind of Islam which compromises with the previous traditions as represented by Javanese abangan, wetu telu of Sasak and the gumai in North Sumatera. In Sundanese case, however, there is no special term to denote this tradition. Robert W. Hefner called this locally oriented Islamic tradition as "the non-standard Islam" which doesn't conform to the Sunni standard in the normative point of view. ${ }^{4}$

of South-East Asian Islam), held by Islamic State University (UIN) Syarif Hidayatullah, Jakarta, September 2015.

2 Clifford Geertz, Religion of Java (New York: Free Press, 1960).

3 There are things to argue concerning the phenomenon of Sundanese muslim in which the legacy of Hinduism didn't seem to be significant in their recent life as it is found in Javanese. One of the strong reason was proposed by Jakob Sumardjo, that the weakness of Hinduism legacy was caused by the absence of the powerful and aggressive kingdom as the center of socio-political cohesion and the guardian of the religious patronage. This is because of the primordial nature of Sundanese people, which are the unirrigated rice field community (masyarakat ladang/huma) and due to the hilliness character of topographical circumstances. Jakob Sumardjo, Arkeologi Budaya Indonesia; Pelacakan Hermeneutis-Historis Terbadap Artefak-Artefak Kebudayaan Indonesia (Yogyakarta: Penerbit Qalam, 2012), pp. 33-36.

${ }^{4}$ Hefner's conclusion has shown the decline of this group in contemporary Indonesia due to some circumstances, including the displacement of localized economies, societies, and subjectivities by those of a more global cast, and the success of Islamic 
What Hefner refers as the "non-standard" Islam is actually a continuation of what had done before by researchers, including M. C. Ricklefs notion of "the mystic-synthesis" in Javanese Muslim. According to him, in the course of early $19^{\text {th }}$ century, a particular kind of Islam arose in Javanese society; the "mystic synthesis", which basically has three notable characteristics: Javanese held firmly to their identity as Muslim, they carried out the basic ritual of obligations of the faith, but they also accepted the reality of local spiritual forces. ${ }^{5}$

The passages of this paper can be seen as a supplement to the findings of Geertz, Hefner, and Ricklefs through Sundanese case. It aims to pose a contribution to the study of Sundanese Muslim in terms of indigenous local tradition and the traces of Islamization within. It will also propose some remarks on the passages above through the existence of pananyaan and their "shifts" in the anthropological point of view, from its possible origins to the present.

\section{Pananyaan: A Sundanese "Islamicate" Culture}

Marshall Hodgson's notion of the term "Islamicate" is highly relevant in this elucidation. It refers not directly to Islam itself, but to the social and cultural complex historically associated with Islam and the Muslims, both among Muslims themselves and even when found among non-Muslims. ${ }^{7}$ In the course of post-orientalist approach to Islamic studies, Hodgson has a considerable influence in resituating historical analysis of the formation of the Islamic tradition. ${ }^{8}$ In this case, the existence of pananyaan which is the composite of Islamic spectrum and Sundanese local customs has directly reflected the "Islamicate" culture.

The rural Sundanese commonly recognize what so-called pananyaan (literary means "who is asked" or the place/someone to ask), - as it has

reformist to outflank their syncretic rivals by creating collaboration with the state patronage. Robert W. Hefner, "Where have all the abangan gone?", in Michel Picard (ed.), The Politics of Religion in Indonesia; Syncretism, Orthodoxy and Religious Contention in Java and Bali (New York: Routledge, 2011), pp. 71-73.

5 See M. C. Ricklefs, Polarising Javanese Society: Islamic and Other Visions (c, 1830-1930) (Singapore: NUS Press, 2007), pp. 3- 6.

6 This chapter is brief summary of Asep N. Musadad, "A Preliminary Sketch on Pananyaan and Their Magical Spells in Sundanese Culture", with some modifications.

7 Marshall Hodgson, The Venture of Islam (Chicago: The University of Chicago Press. 1974), vol. 1, p. 59.

8 Carl W. Ernest and Richard Martin, Retbinking Islamic Studies (Columbia: The University of South Carolina Press, 2010), p. 7. 
already been used until today - as someone who has ability to reveal the world of unseen (nu gaib) in a lot of terms and give some advices on all problems brought to him. The term also genealogically has its old legacy from early $16^{\text {th }}$ century Sanghyang Siksakandang Karesian manuscript. It is said that the wellspring of the pleasure was basically represented in this symbolism (siloka) of Dharma Pitutur; "the story of lake told by the swan, elephant told the story of forest, fish told everything about sea, and all about flower was told by beetle". ${ }^{9}$ It means that someone must be careful when he wanted to do something and not to make a mistake when looking for something or someone to ask (ulah salah gosan nanya). ${ }^{10}$

Although it couldn't be confirmed about the first official usage of word pananyaan, as understood by rural Sundanese today, the core meaning for the term has been existed since $19^{\text {th }}$ century, or earlier. Mustapa has mentioned dukun, pandita, ulama, malim, kuncen, and paraji as the "places to ask". ${ }^{11}$ As mentioned earlier, Sundanese people today, recognise pananyaan as someone who has ability to reveal the world of unseen (nu gaib), relating to all human needs.

Something which later become the field to explore, is the contact between pananyaan and Islamic teaching. As stated by Federspiel, at the time of Islam's arrival, the role of shaman (dukun) played the important role according to the folk of Malays. There were at least two different types of shaman at that time; the "healer" who used a vast array of herbs, potions, massage, magic formulas, and various other device, and the "sorcerer", a foreteller of auspicious and inauspicious occasion who could also cast spells and give advice on all manner of problems brought to him. These practitioners were in place when Islam arrived. ${ }^{12}$ The similar case seems to be happened in the rest of Indonesian regions where Islamic spectrum and various local customs created the hybrid cultures.

Concerning Sundanese context, the Mustapa's late $19^{\text {th }}$ century

\footnotetext{
9 Atja and Saleh Danasasmita, Sanghyang Siskandang Karesian; Naskab Sunda Kuno 1518 Masehi (Bandung: Proyek Permusiuman Jawa Barat, 1981), p. 13, and p. 39.

10 Ibid.

11 Based on Astrwijaya's translate, the Indonesian version of the Mustapa's statement is "tempat bertanya"/"place to ask" (tempat tatanya). Meanwhile, i haven't been able to find the original Sundanese version. It doesn't rule out the possibility that Mustapa used the word pananyaan when identifying these group of people.

${ }^{12}$ Howard M. Federspiel, Sultans, Shamans, and Saints; Islam and Muslims in Southeast Asia (Honolulu: University of Hawaii Press, 2007), pp. 69-70
} 
reports, ${ }^{13}$ reflected the confirmation for Federspiel thesis. It has provided such fairly clear picture of the occult beliefs and practices among Sundanese people along with the intensification of Islam. Some local practitioners such as dukun, pandita, panyebor, paraji, and tukang ngalokat were in proper place along with ajengan, the Islamic priest and propagator. By $19^{\text {th }}$ century, Mustapa has also explained ajengan as a healer in a different sense with that of traditional practitioners. When someone asked him to heal a certain disease, ajengan will simply recite some Islamic prayers $\left(d o^{\prime} a\right)$. Accordingly, the phrase that is identical to ajengan is "the blessing of prayers" (barokah do'a). ${ }^{14}$

The word pananyaan today, has made a reference to above-mentioned practioners and embodied in one contemporary fashion. Most, if not all, of today pananyaan are the adherent of Islam. In this case, it is important to find out the distinguishing characters between pananyaan and ajengan. As stated by Mustapa, those who studied in Pesantren - who in turn will be an ajengan - were respected by their vast knowledge about Islamic teachings, whereas a pandita - which denoting the similar meaning to pananyaan - was widely recognized by their traditional incantations and supernatural power..$^{15}$

Shortly speaking, both of pananyaan and ajengan are mainly representing two distinct dimensions; "religious cult" and "magical cult". The accentuation of ajengan was all about Islamic priesthood and indoctrination of its teachings. However, - still based on Mustapa's 19th reports, the double roles (religious \& magical) possessed by an ajengan has gained more popularity. ${ }^{16}$

From Dukun to Pananyaan: Continuity and Change in Sundanese Tradition

Confirming Geertz, the religion of Java, particularly of the peasantry, is a composite of Indian, Islamic, and indigenous Southeast Asian elements. The result was a balanced syncretism of myth and ritual in which Hindu Gods and Goddesses, Moslem prophets and saints, and

\footnotetext{
${ }_{13}$ R.H. Hasan Mustapa, Adat Istiadat Sunda, trans. M. Astrawijaya (Bandung: Penerbit Alumni. 1998), p. 180.

14 Ibid.

15 Ibid.

16 Ibid., p. 215
} 
local spirits and demons all found a proper place. ${ }^{17}$ The detailed discussion below will examine Geertz statements in case of Sundanese pananyaan.

As the starting point, one should note that pananyaan today is clearly distinguished from dukun (shaman) or tukang telub (witches). Sundanese nomenclature has shown the bad connotation to later terms, whereas pananyaan remains a good one, due to the penetration of Islamic spectrum coloring this tradition. Mustapa's report has conform the existence of dukun as one of the "places to ask" in various problems, including healing the sick. In terms of local practitioner, dukun and tukang ngalokat were the indigenous group in Sundanese-Priangan.

It is important to note that Mustapa's statement also mentioned ajengan, the Islamic propagator, in a proper place in similar manner as dukun. There is no polemical account can be found in Mustapa's statement, except the distinguished technical language which in turn reflects the different way of healing; when someone healed over and getting well from the illness after treated by a dukun, it was said; dijampe (he was healed by magical spells) or ditumbal (he was healed by a tumbalsacrificed things to prevent disease of misfortune), whereas the phrase that is identical to ajengan is "the blessing of prayers" (barokah du' $a$ ).

In addition, it is well-remembered by Nini Itoh (65 years old), an elder in Tasikmalaya, that in the times of youth there were many Sundanese dukun who practiced ngamat or nyambat, a Sundanese term to denote the spiritualism; invoking ancestral spirits and let them taking over his body until he is in a trance before holding a conversation with the client concerning the problems. In overcoming various problems, they invoked certain helping spirits to generating the power in shamanic rituals.

It has been well-known that one of the most remarkable Sundanese magical sciences from long time was invoking ancestral spirit called elmu pamacan. It has also become Sundanese shamanic feature practiced by a dukun as stated above. Some of those who possess such ability believe that the spirits of certain ancestors are transformed into the totemic tiger spirits (macan/manng), which domiciled in Leuweung Sancang in Southern part of Garut and henceforth become the vassals of Prabu Siliwangi, the most famous king of Pajajaran Kingdom. The legacy of spiritualism, which is the indigenous Southeast Asian element and the

17 Clifford Geertz, "Ritual and Social Change: A Javanese Example", in Clifford Geertz, The Interpretation of Culture (New York: Basic Books, 1973), p. 147. 
Hindu-Buddhist myth can be traced here.

Studying on religions and beliefs is always related to the concept of the supernatural, both being considered as God, spirit, angels, genie, ghost, and other supernatural beings that are considered having supernatural powers. The idea of supernatural almost appears in every religion and belief, both in modern and pre-literate societies, and exist in every culture and era. ${ }^{18}$ Spiritualism, along with animism, dynamism, fetishism, and the like, are the most archaic forms of the belief toward supernatural beings. These beliefs are what Geertz refers as the indigenous elements of Southeast Asia, which incorporated with Indian and Islamic spectrum.

In the Sundanese case, the practices of spiritualism are still exist up to present day in grass-root world. The practice of nyambat or ngamat is not only held by a dukun or pananyaan. One of the magical feature for those who seek the supernatural power of invulnerability (kadugalan) is elmu pamacan through which they invoke their ancestral spirits which transformed into the tiger spirits to generating the supernatural powers. Several people also believe to have the guardian spirit from their ancestors that can be invoked whenever they need.

During my field research in investigating several pananyaan, I found out that spiritualism was one of their major tenet, particularly in the oldster cases. Here, the point of departure must be employed concerning the practices of nyambat in Sundanese cases. While the traditional healer (dukun) invoked (nyambat) the "local" ancestral spirits like those of tiger spirits of Leuneung Sancang, for example, the pananyaan version of spiritualism is to invoke the spirit of Islamic saints (para wali).

This kind of reconciliatory account can be found, for example, in the case of Uwa Enji Samji (76 years old) a pananyaan in Tasikmalaya, who used to invoke several Islamic saints in his "shamanic" practices. One of the recorded Islamic saint by his own acknowledgment, was Syekh al-Maghriby, from Tunisia. From the normative point of view, he is Muslim who carried out the obligation of faith, even he is one of the khatib jum'at in the central mosque of his village. In some ways, the notable characteristics of "mystic synthesis" in Ricklefs notion as stated earlier, can be found in his personality.

However, these characteristics seem to stand-out in several

18 Ayatullah Khumaini, "The Acculturation of Islam and Local Culture in Bantenese Magic", paper presented in ICSAI (International Conference of South-East Asian Islam), UIN Syarif Hidayatullah, Jakarta, 2015 
Sundanese Muslim in Priangan, up to recent times. Aki Jaka (79 years old), a muadziin, for example, goes to the mosque every day, carried out the obligation of five-times prayers in that mosque, and at the same time practiced elmu pamacan, invoking the tiger spirits from Leuweung Sancang. Thus, the term kolot babeula (elderly people) in Sundanese case, has always blended with the story of supernatural powers.

It is commonly said that most, if not all of kolot baheula have possessed certain supernatural powers. At the same time, they also identical to Islamic identity. Some people believe that the supernatural power was achieved due to their pious and God-fearing quality of life, so the Divine powers are bestowed to them. One of Sundanese proverb states; kolot baheula mah ku bismillah oge bisa ngapung (by only reciting basmalah, the ancestor from the past were able to fly in the air).

In this case, it is important to note that Islam provide a "dominant discourse" above the rest elements within the tradition. Start on the very basic values of being and cosmological account, the Islamic concept of God (Allah) and His power of creation has become a foundational belief of them all. There is no indication for such Hindu-Buddhist elements in their theological belief. In term of ritual in pananyaan cases, Islamic spectrum has also become the grand narration.

Even though invoking spirits, for example, was originated from indigenous local custom, most of procession is covered by Islamic elements; started by theological advices and tawassul, before invoking certain spirit of an Islamic saint. Not only pananyaan, the practice of elmu pamacan is also started by an Arabic tawassul, although the invoked spirit is originated from Leuweung Sancang. The case is similar to kolot baheula, those who confirm the Islamic identity and at the same time also accept the reality of local supernatural power.

From the normative point of view, this particular kind of Islam has also reflected the "non-standard Islam" in Hefner's term. The measure of his dichotomy based on whether one tradition is considered as "religion" or "adat karubun" (local/ancestral customs). In the more specific abstraction, the standard of "religion" in the case of Indonesian Muslim is the "Sunni" standard. As Hefner stated, the eyes of many reformist Muslims, the main characteristic of abanganism, for example, is that it does not yet conform to the Sunni standard, and as such does not qualify as either 'Islam' or 'religion' (Agama). ${ }^{19}$

${ }^{19}$ Hefner, "Where have all the abangan gone?", p. 74. 
If what is meant by Hefner is the incompatibility of the ritual practices, the above-explanation can be considered as "non-standard", duet to the "additional" local practices in their religious life and believe system, which is the belief of local supernatural forces. In the case of basic obligation as a Muslim, they performed five-times prayers (solat lima waktu) and the rest of the five pillars of Islam. The only considerable "addition" is the belief and the practices of local supernatural powers which integrated in the characteristics of Riclekf's "mystic synthesis".

In this case, it can be concluded that the intersection between Islam and local customs was in the terms of substantive and elementary form; which is the believe system and the basic obligation which didn't achieve the penetration of complex Islamic symbols in daily life. However, in terms of the basic of religious conception of God, they all are the same. They recognize Islamic conception of God (Allah), the Almighty and His absolute power of creation that covers all the matters, including the reality of local supernatural powers.

\section{Ahli Hikmah: The Islamic Spectrum of Pananyaan}

Here the emergence of abli bikmah, an Islamic term which indirectly representing the Arabic occultism, has found its momentum in shaping the compromises between Islamic spectrum and local customs. As stated by Mustapa, an ajengan who possess magical powers has gained more popularity. In this intersection, the contact between Islamic spectrum and local supernatural powers has achieved the level of the outward appearance.

Ahli bikmah - as shown by Sundanese-Priangan people - has been identical to those who expert in Islamic occultism, which is differ from that of ajengan in many ways. However, people of Tasikmalaya, for example, simply conceive this word in the occult term as "the expert of Islamic supernatural knowledge". Abli bikmah henceforth became part of pananyaan's large family and contributed as one of major determinant element. Thus, the syncretic process and the origination of the lately established abli bikmah were creatively took part.

The previous "exorcist" and "occult" stuffs like menyan (incense derived from gum benzoin), hand-made doll (puputrian), lemongrass, panglay, jaringau, and the others were slowly replaced by the water (cai) which is believed as Islamic stuff. In this moment of substitution, the Arabic occultism began to flow into Sundanese speaking area-especially through the hand of Javanese-and creatively grasped by Sundanese 
Muslim.

It is important to note that the accounts of Arabic occultism as it is contained in various bikmah books such as Syamsul Ma'arif al-Kubra, Manba' Usul al-Hikmah, al-Sirr al-Jalil, al-Mujarrabat, and the like, was penetrated by some ajengan hikmah. In such a case, the important role of pesantren can be traced in this elucidation, although it needs the further research. In the case of Sundanese Priangan, the wave of Islamization came from the east, through Demak at the first wave, and Mataram-Islam at the second. Thus, the Javanese influence was necessarily flows in the process of Islamization with Cirebon and Banten as two major gates.

In pananyaan context, what I mean with the outward appearance is the penetration of such Arabic account in their practices. The most representative one is the "bijib" (hijib nawawi, syadzili, akbar, etc.), and "birz" (hirz yamani, etc.) which are considered as high-level Islamic supernatural powers possessed by ajengan which originated from muslim saints (auliya). In addition, the popular example for this intersection is the emergence of "aji saepi" (saepi angin, banyu, geni, etc.), which is the "hybrid" supernatural power.

One should note that the Arabic occultism is flow through ajengan from pesantren. Not only in the inward aspect, the shift in the supernatural power into Arabic occultism also occurred in its outward appearance. At this rate, the dichotomy between 'amalan (Arabic incantations) and jangjawokan (Sundanese magical spells) comes on the scene. It can be said that in early times, the existence of both are equaly popular. As reflected in Mustapa's reports, the existence of jampe (spells for healing) were widely used, in addition to "barokah dua' a" from ajengan.

\section{Testimonies from the Sundanese Incantations}

In previous paper, I have made a classification of so called "hybrid incantation" in which Islamic expression and local language were mixed in one passage of magical spells. With regard to the language composition, the way of mixing the spells can be divided into several "creative" ways: ${ }^{20}$ Pure Arabic incantation (amalan/wirid); Pure Sundanese language with Islamic content (theme); Mixture of Sundanese language and Arabic Islamic expression; Mixture of Sundanese language and special Qur'anic verses; Sundanized Qur'anic

20 Asep N. Musadad, "Tracing The Cultural Changes in Sundanese Local Incantations", in Analisa: Journal of Social Science and Religion, Vol. 1, No. 1 (June 2016), p. 80. 
verses.

According to Federspiel, Islam unwittingly gave the pre-Islamic local practitioners some new material to work. Arabic expressions, particularly the key Islamic ones, such as "the confession" (shahadab), "the remembrance" (dhikr), the "opener" (bismillah) to the Qur an, and the "magnificat" (takbir), were taken over as incantations, sometimes replacing, but more often supplementing the Sanskrit expressions. ${ }^{21}$ In many ways, this stage of "combining" Islamic expression with the local incantation has representatively recorded the development of assimilation of both.

The importance of these incantations lies in the historical information within. All of these hybrid incantations are used the "new Sundanese" language that receive large influence from Javanese Mataram which imposed its influence in Priangan area since $17^{\text {th }}$ century AD. Before that one, the so-called "old Sundanese" (Sunda Buhun/Kuna), in both of language and script had existed as a distinct language in West Java.22 This means that the art of mixing incantations in Sundanese Priangan region was highly influenced by Mataram-Islam's legacy and occurred after $17^{\text {th }}$ century AD.

The further abstraction suggests that the intensification of Islam di West Java, especially Priangan region, was "politically" and "culturally" a continuation of the Sultan Agung's legacy of the "mystic synthesis" in penetrating Islam from north littoral to the "back country" of Java-land. In the other hand, some hybrid incantations ${ }^{23}$ have shown Cirebon that one of the major source of Islamization in Sundanese Priangan. The spreading of certain incantations in several different region has also become a part of cultural diffusion in the web of mystic-synthesis in West Java.

${ }^{21}$ Federspiel, Sultans, Shamans, and Saints, p. 245

22 Mikhiro Moriyama, "Discovering The Language and The Literature of West Java", in Journal Southeast Asian Studies, Vol. 34. No. 1 (June 1996), p. 153.

23 One of the most representative sample is the spell for long trip which widely used either by pananyaan or the ordinary elder people in Tasimalaya. The spell goes as follows: Bismilabirohmanirobim. Indit abdi jeung Kanjeng Nabi Ibrobim. Leumpang abdi jeung Kanjeng Nabi Muhammad. Dipayungan abdi ku Gusti Alloh. Dudu pujiningsun. Pujine Kangjeng Sinubun Yabu. Nu ngadeg di Gunung Jati. Anggala cahyaning burip. La Ilaha Illallah. 


\section{Pananyaan and Contemporary Shaman}

The ultimate meaning of pananyaan today actually encompasses the significance of shaman, traditional healer, spiritual practitioner, astrologer, and - in turn - Islamic priest. The worldly things are touched and shaped by heavenly determinations, even though the dichotomy between rational and irrational or explainable-unexplainable has been made by the "patients" themselves. It is what Christina Pratt refers to be "the contemporary shaman". Today, shamans who help people with professional concern involving careers, success, and recognition, while in the past, their primary role was healing and hunting. ${ }^{24}$

Yayat Ruhiat (25 years old), a youth in Tasikmalaya didn't dare to start a new profession before asking a pananyaan. In gaining progress, he also consulted to them. It is true that in the mindset of today Sundanese people, the nature of both "terrestrial world" and "heavenly bodies", seem to be distinguished in such dichotomous way. Nevertheless, they are apparently still holding on something that is considered "irrational" as otherworldly forces, and ask the pananyaan in doing such a correspondence.

In this case, those who ask to pananyaan, believe in double causality of things; visible and invisible "reason". They believe in such invisible causality of all matters and ask the pananyaan to solve the various problems-to mention the examples-; healing the sick, seeking a job, rediscovering the lost items, gaining rank and power in the business, family welfare, etc. Accordingly, there are various occult knowledge which are usually possessed by a pananyaan; paririmbon (horoscope), implengan (prophecy), kinasiban (spells to win affection), singlar (spells to expel the evil creatures), jampe (spells for healing), jangjawokan (spells for various activities), kabedasan (invulnerability) amalan (special Islamic prayers), and elmu isim/wapak (traditional Islamic teleology), etc.

In the age of technology, there is also a significant shift in pananyaan. As represented by A Anwar (45 years old), the uses of modern stuff have become the part of his practices. In treating long distance patients, he uses a hand phone for long distance supernatural treating. Today the image of pananyaan has been identical to Islam. In such a case, the incorporation between Islam and local customs has embodied in one contemporary fashion. For rural Sundanese, the existence of pananyaan as someone to ask in various problems, has a vital significance as well as

${ }^{24}$ Christina Pratt, Encyclopedia of Shamanism (New York: The Rosen Publishing Group Inc., 2007), vol. 2, p. xv 
the ajengan as the Islamic preacher. In many cases, both have interchange each other, although the distinction has been made.

\section{Pananyaan and Ruqyah; Islamization of Tradition in West Java}

In Nagrog village (2009), Tasikmalaya, Imas (41 years old) has long felt harassed and haunted by a genie. For some month, she never slept well, - according to her belief - due to the annoyance of that evil creature. From time to time, her parents have tried to treat that strange problem. Several pananyaan from all over West Java have been brought to expel the satan within herself. But none of them were able to solve the problem, until she met her younger brother from Jakarta, who suggested her to do a ruquah, a newly method to cure such a disease, which also considered as a "prophetic" method. After take a ruqyah, she can sleep well and the problem has solved.

The above phenomenon has reflected a natural pattern of things in the realm of cyclical history; that everything is repeated in the different time and place. Mustapa's report in 19th century ${ }^{25}$ has also recorded the same case. Those who have a mysterious illness which can't be handled by dukun, or pandita, would be healed by tukang ngalokat, who has a highest degree of supernatural power. The pattern of revolving historical actor always reflected the same from time to time.

In the case of Indonesian Islam, the above-mentioned passage has shown the dawn of the most puritanical form of Islamic supernatural treating. In this case, the Arabic penetration has replaced almost all practices, not to say totally replaced. Many things to argue concerning this kind of substitution. The various developments of pananyaan, as mentioned above, are determined by some factors that responsible to shape the direction of Indonesian Islam, which Hefner refers as the "Sunni standard".

According to Federspiel, there are three interrelated groups were responsible for developing standard Sunni religious thought in Indonesia: the immigrant Muslim group, primarily Arabs from the Hadramawt, the religious officials in the schools and mosques, and the Muslim merchants. ${ }^{26}$

In this case, I want to highlight the religious official in the schools and mosques as the considerable determination in the continuity and

\footnotetext{
25 Mustapa, Adat Istiadat Sunda, p. 118.

${ }^{26}$ Howard M. Federspiel, Islam and Ideology in The Emerging of Indonesian State (Leiden: Brill, 2001), p. 14.
} 
change of pananyaan. As pesantren has played a significant role in shaping the pananyaan, after the fall of new-order, the spread of lately established religious institutions which differ in many ways from Islamic spectrum of pesantren, has also influenced the development of pananyaan. Shortly speaking, the puritan movement which grow rapidly since 1980 along with the modernization, is coming on the scene, and the "still-taking place Islamization" seems to be continued.

\section{Conclusion}

The reflection on the development of pananyaan leads to several conclusions. First, there are several major shifts in the origins pananyaan to the present; the shift of domestic spiritualism from local spirit to Islamic saints, that reflected an elementary form of the intersection of Islam and local customs. Second, the emergence of abli hikmah, that reflected such an outward appearance in the intersection as represented by several hybrid incantations and supernatural powers. Third, the contemporary shaman, whose Islam and local customs are united in one fashion with influenced by modern determinations. In addition, the still-taking place of Islamization has become a challenge for the existence of pananyaan.]

\section{References}

\section{Books and Articles}

Atja and Saleh Danasasmita. Sanghyang Siskandang Karesian; Naskab Sunda Kuno 1518 Masehi. Bandung: Proyek Permusiuman Jawa Barat, 1981.

Bowen, John R. A New Anthropology of Islam. Cambridge: Cambridge University Press, 2012.

Ernest, Carl W. and Richard Martin. Rethinking Islamic Studies. Columbia: The University of South Carolina Press, 2010.

Federsfiel, Howard M. Islam and Ideology in Emerging of Indonesian State Leiden: EJ. Brill, 2001.

-------. Sultans, Shamans, and Saints; Islam and Muslims in Southeast Asia. Honolulu: University of Hawaii Press, 2007.

Geertz, Clifford. "Ritual and Social Change: A Javanese Example". in Clifford Geertz, the Interpretation of Culture. New York: Basic Books, 1973. 
Religion of Java. New York: Free Press, 1960.

Haviland, William A. et. al. Cultural Anthropology 12th Edition. Belmont: Thomson Wadsworth, 2008.

Hefner, Robert W. "Where Have all the Abangan Gone?". in Michel Picard (ed.). The Politics of Religion in Indonesia; Syncretism, Orthodoxy and Religious Contention in Java and Bali. New York: Routledge, 2011.

Hodgson, Marshall. The Venture of Islam. Chicago: The University of Chicago Press, 1974.

Khumaini, Ayatullah. "The Accultration of Islam and Local Culture in Bantenese Magic". paper presented in ICSAI (International Conference of South-East Asian Islam), UIN Syarif Hidayatullah. Jakarta, 2015.

Moriyama, Mikhiro. "Discovering the Language and the Literature of West Java". Journal Southeast Asian Studies. vol. 34. no. 1, June 1996.

Musadad, Asep N. "A Preliminary Sketch on Pananyaan and Their Magical Spells in Sundanese Culture". paper presented in ICSAI (International Conference of South-East Asian Islam), UIN Syarif Hidayatullah. Jakarta, 2015.

-------. "Tracing the Cultural Changes in Sundanese Local Incantations". in Analisa: Journal of Social Science and Religion. Vol. 1, No. 1, (June 2016).

Mustapa, R.H. Hasan. Adat Istiadat Sunda, trans. M. Astrawijaya. Bandung: Penerbit Alumni, 1998.

Pratt, Christina. Encyclopedia of Shamanism. New York: The Rosen Publishing Group Inc, 2007.

Ricklefs, M. C. Polarising Javanese Society: Islamic and Other Visions (c, 1830-1930). Singapore: NUS Press, 2007.

Spradley, James P. Participant Observation. New York: Holt. Rinehart and Wilson, 1980.

Sumardjo, Jakob. Arkeologi Budaya Indonesia; Pelacakan Hermeneutis-Historis Terbadap Artefak-Artefake Kebudayaan Indonesia. Yogyakarta: Penerbit Qalam, 2012.

\section{-------. Simbol-Simbol Artefak Budaya Sunda. Bandung: Kelir, 2003.}

Tamney, Joseph. "Modernization and Religious Purification: Islam in Indonesia". in Reviews of Religious Research. vol. 22. no. 2, 1980. 
Yahya, Iip D. "Dari Galunggung ke Tasikmalaya". in Historia Soekapoera. Vol. 1. No. 1. 2013.

\section{Interview}

Interview with A. Anwar (43), Kawalu, Tasikmalaya, West Java, c. 2014-2015.

Interview with Aki Amir, (d. 2015), Kawalu, Tasikmalaya, West Java, March 2014.

Interview with Aki Jaka (d. 2017), Kawalu, Tasikmalaya, West Java, March 12 2015.

Interview with $\mathrm{Ki}$ Ade (66), Kawalu, Tasikmalaya, West Java, c. 2014-2015.

Interview with Nini Itoh, (64), Kawalu, Tasikmalaya, West Java, September $15^{\text {th }}-17^{\text {th }} 2015$.

Interview with Wa Enji Samji (d. 2017), Kawalu, Tasikmalaya, West Java, c. 2014-2015 